\title{
Reducing Competitive Victimhood in Kosovo: The Role of Extended Contact and Common Ingroup Identity
}

\author{
Luca Andrighetto \\ University of Milano-Bicocca
}

Silvia Mari

University of Milano-Bicocca

Chiara Volpato

University of Milano-Bicocca

Burim Behluli

University of Prishtina

\begin{abstract}
During intractable conflicts, "competitive victimhood" refers to the subjective belief that one's own ingroup has suffered more than the outgroup. Although competitive victimhood is considered an important inhibitor of reconciliation processes, no research has attempted to examine ways of reducing it. The present study aims to fill this gap. Kosovar Albanians students $(\mathrm{N}=170)$ were asked to report their perception of ingroup and outgroup victimhood during the protracted violence between Serbs and Albanians in Kosovo. Our findings revealed that frequent and high-quality extended contact with outgroup members and identification with a common ingroup reduced competitive victimhood. The effects of extended contact and common ingroup identification were fully mediated by increased perspective taking and trust toward the outgroup, and by decreased outgroup infrahumanization. The implications of these results for restoring fractured intergroup relations are discussed.
\end{abstract}

KEY WORDS: intergroup reconciliation, competitive victimhood, extended contact, common ingroup identity

\section{Introduction}

During intractable conflicts, both the involved parties experience severe physical and psychological sufferings. However, people often interpret the impact of the conflict subjectively, viewing their own group as the only legitimate victim and the rivals as the illegitimate perpetrators of unjust and immoral misdeeds (Bar-Tal, Chernyak-Hai, Schori, \& Gundar, 2009; Nadler \& Saguy, 2003). This self-perceived sense of collective victimhood is deeply rooted in individuals and constitutes an integral part of their social identity (Robben \& Suarez-Orozco, 2000) that persists long after the conflict is formally resolved (Bar-Tal et al., 2009; Shnabel \& Nadler, 2008). Such belief has been observed in several communities entrapped in ongoing or recent conflicts. For example, both Israeli Jews and Palestinians perceive themselves as the unequivocal victims of the Israeli-Arab conflict and accuse the 
other group of being the victimizer (Bar-Tal, 2007; Caplan, 1999; Rouhana \& Bar-Tal, 1998). The same holds true for Catholics and Protestants in the violent context of Northern Ireland (Cairns, Mallet, Lewis, \& Wilson, 2003), Greek and Turkish in Cyprus (Hadjipavlou, 2007), or Serbs and Croats in the former Yugoslavia (Ajduković \& Čorkalo Biruški, 2004; Kosic \& Tauber, 2010; Volkan, 1997).

According to Noor and colleagues (Noor, Brown, Gonzalez, Manzi, \& Lewis, 2008; Noor, Brown \& Prentice, 2008), when intergroup relations are based on conflicts about social or material resources, the sense of victimhood may interplay with group members' intrinsic need to compete with the outgroups (Brewer \& Brown, 1998; Hewstone, Rubin, \& Willis, 2002). Thus, individuals may not only focus on ingroup victimhood, but also engage in a real competition with the outgroup over who has suffered more. Claiming that one's own group has been victimized more than the other group may serve different purposes for group members. First, it may represent a way to escape guilt or responsibility for ingroup misdeeds during the conflict (Smyth, 2001). It may also allow the group to draw the attention of the international community toward its diminished condition (Bar-Tal et al., 2009). More importantly, in a postconflict era, competitive victimhood may rationalize acts of revenge against rivals, instigating a cycle of violence that can persist for generations (see Nadler \& Saguy, 2003). For these reasons, the competitive victimhood construct plays a key role in decreasing the prospect for future peaceful coexistence between groups, by moving people away from reconciliation. Recent studies have empirically reported the detrimental effects of competitive victimhood on intergroup reconciliation processes. Noor and colleagues showed that in Northern Ireland this kind of competition decreases the Protestants' and Catholics' inclination to forgive each other (Noor, Brown et al., 2008; Noor et al., 2008) and, at the same time, reduces the willingness to accept responsibility for the ingroup's past acts of violence. Similarly, in Chile, competitive victimhood among Pinochet opponents was a negative predictor of their willingness to forgive Pinochet supporters (Noor, Brown et al., 2008).

Despite this evidence, research on this topic is still in its infancy. To date, there are no studies showing social psychological strategies that might limit the negative effects of competitive victimhood on postconflict intergroup relations. In the present work, carried out in Kosovo, we endeavor to take the first step in this direction. Our aim is to test whether extended contact (Wright, Aron, McLaughlin-Volpe, \& Ropp, 1997) and identification with a common ingroup (see Gaertner \& Dovidio, 2000) can reduce competitive victimhood. We also aimed to reveal the processes underlying these relationships.

\section{Intergroup Contact in Segregated Societies}

Considerable evidence demonstrates that intergroup contact is a powerful strategy for ameliorating intergroup relations (see Pettigrew \& Tropp, 2006, for a meta-analysis), and recent studies have revealed its effectiveness in postconflict reconciliation (see Hewstone et al., 2008). For instance, Hewstone and colleagues (e.g., Hewstone, Cairns, Voci, Hamberger, \& Niens, 2006) showed that frequent and positive contact between Protestants and Catholics led each group to forgive the other for past misdeeds. These effects were driven by increased intergroup trust (Hewstone et al., 2006), intergroup empathy and perception of the outgroup's humanity, and by reduced anger toward the outgroup (Tam et al., 2007). Similarly, Čehajić, Brown, and Castano (2008) reported that the contact between Bosnians and Serbs in Bosnia-Herzegovina increased the Bosnians' willingness to forgive Serbs through enhanced perspective taking, trust, and perception of outgroup heterogeneity.

Despite the indubitable benefits of contact on intergroup relations, this strategy cannot be applied in all situations. Indeed, contact can be implemented only when people have the opportunity to actually meet members of the other group (Crisp, Stathi, Turner, \& Husnu, 2008; Phinney, Ferguson, \& Tate, 1997; Turner, Hewstone, Voci, \& Vonofakou, 2008). In many postconflict 
contexts, such opportunities simply do not exist. In Kosovo, for instance, the Albanian and the Serbian communities are currently strictly segregated. Since the conflict, the Serbs have lived in isolated enclaves checked by international forces. Such segregation persists in different domains of the society: A parallel system of education has been established (Kostovicova, 2009), people are treated in different healthcare systems (Bloom, Hoxha, Sambunjak, \& Sondorp, 2007), and the two communities are managed by separate administrations (Kostovicova, 2005; Winther, 2007). For these reasons, interventions that involve direct contact can be very difficult to carry out.

One potential alternative strategy for affecting intergroup attitudes is to consider an extended form of contact. Wright and colleagues (1997) suggested that the mere knowledge that an ingroup member has a positive relationship with an outgroup member might be sufficient for reducing prejudice.

Extended contact has been proven to be effective across several problematic intergroup relations, including Protestants and Catholics in Northern Ireland (Paolini, Hewstone, \& Cairns, 2007; Paolini, Hewstone, Cairns, \& Voci, 2004; Tam, Hewstone, Kenworthy, \& Cairns, 2009; Turner, Hewstone, Voci, Paolini, \& Christ, 2007), Whites and African-Americans in the United States (Wright et al., 1997), Whites and South-Asians in the United Kingdom (Turner, Hewstone, \& Voci, 2007; Turner et al., 2008), Germans and immigrants in West and East Germany (Wagner, Van Dick, Pettigrew, \& Christ, 2003), and Italians and immigrants in Italy (Vezzali, Stathi, \& Giovannini, 2012). In addition, research has identified some of the mechanisms underlying the effects of extended contact: reduced intergroup anxiety, increased inclusion of the outgroup in the self, and the perception of positive ingroup and outgroup norms (Turner et al., 2008; Wright et al., 1997).

In the present study, we examined whether extended contact was an effective strategy for reducing competitive victimhood. We assumed that observing frequent and positive relationships between an ingroup and an outgroup member may increase individuals' awareness of outgroup sufferings, thereby decreasing the tendency to overemphasize ingroup victimization and devalue outgroup suffering.

\section{The Benefits of Identification With a Common Ingroup}

According to social identity theory (Tajfel \& Turner, 1986), in certain situations ingroup identification may negatively affect people's attitudes and behavior toward outgroups (see Reynolds \& Turner, 2001). In postconflict settings, high levels of identification with one's own ethnic or religious group have been shown to decrease feelings of guilt for past ingroup misdeeds (Myers, Hewstone, \& Cairns, 2009), to inhibit the orientation toward forgiveness (Myers et al., 2009; Noor, Brown et al., 2008; Noor et al., 2008), and to strengthen the interpretation of past ingroup violence as a form of self-defense (Noor et al., 2008).

On the other hand, studies on the common ingroup identity model (CIIM; Dovidio, Gaertner, \& Saguy, 2009; Gaertner \& Dovidio, 2000) found lower levels of bias and prejudice toward the outgroup among people who perceived themselves as belonging to a common group that includes both ingroup and outgroup members and who identified with this superordinate category (e.g., Capozza, Vezzali, Trifiletti, Falvo, \& Favara, 2010). Consistently, Wohl and Branscombe (2005) found that Jews felt more forgiving toward Germans when they were encouraged to think of the two groups in terms of a superordinate entity (humans) rather than when induced to think of belonging to only their own group. In the same vein, Noor, Brown et al. (2008) reported that high levels of identification with the superordinate group (Chileans) among Pinochet supporters and Pinochet opponents were positively associated with intergroup empathy, trust, and willingness to forgive the outgroup. Further, Gaunt (2009) found that the identification with the common group of "Israelis" weakened Israeli Arabs' tendency to infrahumanize Israeli Jews.

Nevertheless, in many national contexts subgroups are not equally represented within the superordinate group; rather, one specific subgroup may make up a large percentage of the 
superordinate group. For example, in Bosnia-Herzegovina, Čehajić and colleagues (2008) found that the common ingroup of Bosnians largely overlapped with the subgroup of Bosniaks, which resulted in a positive correlation between the two levels of identification. Specifically, the authors showed that only a "relative" common ingroup identification, over and above the subgroup identification, could effectively promote intergroup forgiveness and decrease the social distance between groups.

In line with the above reasoning, we expected to find a similar relationship in our research context between identification with the ingroup and identification with the common ingroup. Indeed, in Kosovo the perception of the supposed superordinate category of Kosovars overlaps primarily with Albanian ethnicity (see Kelmendi \& Desku, 2005). Accordingly, Albanians' high identification with their own group should also correspond to a high identification with Kosovars, resulting in a positive correlation between the two levels of identification. Therefore, here we consider the common ingroup identification with Kosovars after removing the effects of identification with the subgroup of Albanians.

Our aim is to verify whether such "relative" common ingroup identification may decrease competitive victimhood. Because perceiving the ingroup and the outgroup as belonging to a single enlarged group enhances the impression that the two groups share a similar fate (Brewer, 2000), it is plausible to hypothesize that a high degree of common ingroup identification would predispose individuals to believe that outgroup members are victims of the conflict as much as ingroupers. As a consequence, claims that the ingroup has suffered more than the outgroup should be reduced.

\section{The Path Toward Reduced Competitive Victimhood}

Intergroup trust, cognitive empathy (i.e., perspective taking), and the perception of outgroup humanity are crucial variables in repairing fractured intergroup relations (see Nadler, Malloy, \& Fisher, 2008, for a review). In particular, several studies have shown that these constructs are key mechanisms driving the effects of intergroup contact on the promotion of intergroup forgiveness (Čehajić et al., 2008; Hewstone et al., 2006; Tam et al., 2007). In the present article, we aim to extend the investigation of these mediators within postconflict contexts. More specifically, we hypothesize that they can mediate the positive effects of extended contact and common ingroup identification on competitive victimhood.

Trust. Intergroup trust is generally considered an important facilitator of prosocial relations in hostile intergroup settings. Trust allows individuals to overcome the belief that the outgroup has negative intentions toward the ingroup (Mitchell, 2000). This improvement in intergroup attitudes promotes the exchange of knowledge between groups and the development of cooperative and altruistic behaviors (Kramer \& Carnevale, 2001). Growing evidence indicates that intergroup trust increases when frequent and good-quality contact between hostile groups occurs, whether contact is direct (e.g., Čehajić et al., 2008; Hewstone et al., 2006) or via extended relationships (Tam et al., 2009). Furthermore, other studies suggest that common ingroup identification may positively influence the development of intergroup trust (Dovidio et al., 1997; Riek, Mania, Gaertner, McDonald, \& Lamoreaux, 2010).

Perspective taking. Here we propose perspective taking - the ability to understand the perspectives of others (Davis, 1994) — as a further mediator of effects of extended contact and common ingroup identification on competitive victimhood. Numerous studies have documented the substantial benefits of perspective taking for intergroup attitudes (Dovidio et al., 2004; Vescio, Sechrist, \& Paolucci, 2003) and discouraging the stereotype endorsement (Galinsky \& Ku, 2004; Galinsky \& Moskowitz, 2000), in a wide range of contexts, including postconflict (Čehajić et al., 2008; Hewstone et al., 2006). Furthermore, intergroup contact has emerged as an important predictor of this cognitive component of empathy (Aberson \& Haag, 2007; Čehajić et al., 2008; Harwood, Hewstone, Paolini, 
\& Voci, 2005; Hewstone et al., 2006). Given that both extended contact and superordinate group identification reduce the distance between the self and the outgroup, we hypothesized that these strategies would also lead to a better understanding of outgroup members' point of view (i.e., perspective taking), which in turn should limit competitive victimhood. To our knowledge, the positive effects of extended contact and common ingroup identification on perspective taking remain unexplored.

Infrahumanization. Finally, we hypothesized that perception of the outgroup's humanity (Haslam, Loughnan, Kashima, \& Bain, 2008; Leyens, Demoulin, Vaes, Gaunt, \& Paladino, 2007) may be another factor mediating the effects of extended contact and common ingroup identification on competitive victimhood. Such perception can be especially relevant when relationships between groups with a history of violent interactions are examined. Denying others' humanness is one of the main processes through which people justify ingroup violence (Bandura, 1999; Castano \& Giner-Sorolla, 2006) and feel justified in perpetuating aggressive behaviors toward the outgroup (Bar-Tal, 1989). Furthermore, it is an important means of reinforcing boundaries between the ingroup and the outgroup (see Haslam et al., 2008 and Leyens et al., 2007, for a review; see also Capozza, Boccato, Andrighetto, \& Falvo, 2009). By focusing on the emotional side of humanness perceptions, Leyens and colleagues $(2001,2003)$ showed that people tend to infrahumanize outgroup, perceiving outgroup members as less capable than ingroupers to feel uniquely human emotions (secondary emotions; e.g., melancholy, pride), regardless of the emotion's valence. Instead, emotions that human beings share with animals (primary emotions; e.g., excitement, fear) are usually attributed to both the ingroup and outgroup to the same degree. A growing body of evidence shows the negative effects of infrahumanization on intergroup relationships. For instance, Cuddy, Rock, and Norton (2007) reported that infrahumanization was correlated with a lack of motivation to help the victims of Hurricane Katrina in the United States. Both intergroup contact (Tam et al., 2007) and common ingroup identification (Gaunt, 2009) have been revealed as effective inhibitors of such bias. In this study, we tested whether extended contact may be effective in reducing such bias.

\section{The Present Research}

The primary aim of this work is to identify the social psychological factors contributing to alleviate the subjective perception that one's own group has been the only victim of an intractable conflict. In particular, we expected that positive, vicarious experiences of contact with outgroup members and identification with a common group-one that includes both ingroup and outgroup members - would be associated with reduced competitive victimhood. Furthermore, we inspected whether intergroup trust, perspective taking, and outgroup infrahumanization were underlying mechanisms of such relations. Given these constructs' key role in intergroup conflict settings, we proposed a full mediation model (see Figure 1).

As already mentioned, our research context is Kosovo. In February 2008 Kosovo declared its independence from Serbia, becoming the seventh state to emerge from the collapse of the Federal Republic of Yugoslavia. Independence, however, was preceded by years of severe violence between the Albanian and the Serbian communities. Between 1998 and 1999, the Serbian government's "ethnic cleansing" policies resulted in the deaths of approximately 12,000 Albanians (Spiegel \& Salama, 2000) and the displacement of more than 800,000 people (United Nations High Commissioners for Refugees, 1999). This profound victimization led to violent reprisals against the Serbs. Since December 1999, after the North Atlantic Treaty Organization (NATO) intervention, the Serbian community has been the target of murders, repeated threats, arson, and crop burning. As a result, more than 200,000 Serbs have been forced to leave their properties (Internal Displacement Monitoring Center, 2009). 


\section{Method}

\section{Participants}

A sample of 171 students (86 females, 76 males, 9 unknown) were recruited from public high schools located throughout Kosovo, in the towns of Gjilan/Gnijlane, ${ }^{1}$ Pejë/Pec, Ferizaj/Uroševac, and Skënderaj/Sbrica. Age ranged from 16 to 19 years $(M=17.35 ; S D=0.68)$. All participants identified themselves as Kosovar Albanians.

\section{Procedure}

During class time, participants filled out a questionnaire that included the measures described below. The authors in collaboration with a Kosovar bilingual native person prepared the questionnaire in Albanian, by adapting the English version to the Kosovar context. The items were discussed in order to obtain the clearest translation for that social environment. The respondents were instructed as follows: "We invite you to participate in a study of social psychology. The goal of this survey is to explore people's attitudes and perceptions about the current situation in Kosovo. Your responses will be completely anonymous." At the conclusion of the study, all participants were debriefed. A short report with the main objectives and results of the study was subsequently sent to the class leaders.

\section{Measures}

Unless otherwise indicated, responses to all items were given on a 7-step scale, ranging from 1 (strongly disagree) to 7 (strongly agree).

\section{Predictor Variables}

Direct contact. To determine the degree of segregation in the analyzed context, direct contact was first measured. The quantity of direct contact with the Serbian community was assessed by a single item: "How much contact do you have with Serbian people in everyday life?" $(1=$ none, $7=a$ lot). The quality of direct contact was measured with the following item: "In general, when you meet Serbian people, how do you find the contact?" $(1=$ very unpleasant, $4=$ neither pleasant nor unpleasant; 7 = very pleasant).

Not surprisingly, the vast majority of our participants $(n=137,80 \%$ of the whole sample) reported having no direct contact at all with Serbs. This finding highlights the degree of segregation within this context and induced us to exclude direct contact as a predictor in our model.

Extended contact. Participants rated the quantity of extended contact with the following items: "How many members of your family know Serbian people?" and "How many of your friends know Serbian people?" $(1=$ none, 7 = over 10$)$. Two further items measured the quality of this contact: "In your opinion, is the contact that members of your family have with Serbian people pleasant or unpleasant?" and "In your opinion, is the contact that your friends have with Serbian people pleasant or unpleasant?" ( 1 = very unpleasant; $4=$ neither pleasant nor unpleasant; $7=$ very pleasant $)$. Items measuring the quantity of extended contact did not show a satisfactory reliability $(a=.50)$. Given that significantly fewer participants reported having extended contact through friends $(n=67,39 \%$ of the sample) compared with extended contact through parents $(n=114,67 \%$ of the sample), we

\footnotetext{
${ }^{1}$ The first word refers to the city's Albanian name, the second to its Serbian name.
} 
decided to consider only the latter form of extended contact. ${ }^{2}$ Because contact is generally expected to reduce prejudice when it is frequent and cooperative (Allport, 1954), we computed a single index of extended contact by multiplying the scores for the quantity and perceived quality of extended contact (Brown, Maras, Masser, Vivian, \& Hewstone, 2001; Voci \& Hewstone, 2003). ${ }^{3}$

Ingroup identification. The identification with Albanian ethnicity was measured by adapting six items developed by Brown, Condor, Mathews, Wade, and Williams (1986). Examples of items are: "I identify with Albanians of Kosovo" and "I feel strong ties with Albanians of Kosovo." The six items formed a reliable scale $(a=.83)$.

Common ingroup identification. We assessed common ingroup identification with the same items used for ingroup identification, by changing the target group. To avoid a total overlap between the subgroup of Albanians and the superordinate category, we used the phrase "inhabitants of Kosovo territory" rather than "Kosovars." The six items were averaged in a reliable scale $(a=.82)$.

\section{Mediating Variables}

Outgroup trust. We used three items derived from Mitchell (2000; see also Rosenberg, 1957; Noor et al., 2008): "I believe that the majority of Serbian people are fair"; "The majority of Serbian people are well-intentioned people"; "The majority of Serbian people are opportunistic" (reversescored). The three items were aggregated in a reliable measure of outgroup trust $(a=.71)$.

Perspective taking. Perspective taking was assessed with three items adapted from Čehajić et al. (2008): "I try to imagine what Serbian people have gone through in their life"; "I can empathize with what Serbian people have experienced"; and "I find myself moved by the accounts of suffering by Serbian people." The three items were collapsed to form a single index of perspective taking $(a=.67)$.

Infrahumanization. The attribution of primary and secondary emotions to the ingroup and outgroup was measured with 16 emotions derived from Demoulin et al.'s (2004) work. Half of the emotions measured were primary and half were secondary. The eight secondary emotions $(a=.66)$ were: disappointment, gloominess, melancholy, resentment (secondary negative emotions); joy, admiration, hope, and optimism (secondary positive emotions). The eight primary emotions $(a=.61)$ were: pain, irritation, fear, anger (primary negative emotions); pleasure, surprise, enjoyment, and excitement (primary positive emotions). Participants were asked to indicate the extent to which they believed Serbian and Albanian people are likely to feel each of these emotions $(1=$ not at all; $7=$ extremely).

\section{Criterion Variable}

Competitive victimhood. Outgroup and ingroup perceived victimhood was assessed separately, using two matching four-item scale derived from Myers and colleagues' work (2009; see also Noor, Brown et al., 2008, and Noor et al., 2008): "Over the last decades, Serbs [Albanians] in particular have suffered physical and psychological violence"; "Over the last decades, Serbians' [Albanians'] homes in particular were damaged"; "Over the last decades, Serbs [Albanians] in particular had to move because of intimidation"; and "Over the last decades, Serbs [Albanians] in particular were

\footnotetext{
${ }^{2}$ A causal path model, including extended contact through friends, was also performed. Because the effects of this measure of extended contact were unreliable, for ease of presentation such data are not shown here. However, the first author will provide them upon request.

${ }^{3}$ To allow us to include the 57 participants who reported having no extended contact at all, quantity scores were recoded prior to the calculations so that 0 corresponded to no contacts and 6 corresponded to over ten (Čehajić et al., 2008; Voci \& Hewstone, 2003). To reduce the highly skewed distribution of such an index (skew $=2.57$ ), we performed a root square transformation (see Čehajić et al., 2008) which resulted in a remarkable decrease of the skew of the distribution $($ skew $=.80)$.
} 
injured due to armed conflicts." Next, we computed a competitive victimhood index by subtracting the averaged ratings of the Serbian victimhood scale $(a=.84)$ from those of the Albanian victimhood scale $(a=.85)$. The higher the score, the stronger the perception of ingroup compared to outgroup victimhood.

\section{Results}

\section{Introductory Analyses}

Common ingroup identification per se was not significantly correlated with competitive victimhood $(r(170)=-.06, n s)$, whereas ingroup identification was positively correlated with our criterion variable $(r(171)=.20, p=.01)$.

The two levels of identification showed a significant positive correlation $(r(170)=.42$, $p<.001)$. Assuming that this positive correlation was due to the partial overlap of the common group ("inhabitants of Kosovo territory") with the subgroup of belonging ("Albanians"), we conducted a regression analysis to quantify the independent contribution of common group identification separated from ingroup identification. In this regression, the composite score of ingroup identification determined common ingroup identification. For each participant, the standardized residual was recorded and used as an index of common ingroup identification partialized for the effects of ingroup identification (for an example of previous use of this procedure, see Čehajić et al., 2008).

To verify infrahumanization of the Serbian outgroup, emotions were submitted to a 2 (Emotion: secondary vs. primary) $\times 2$ (Group: ingroup vs. outgroup) $\times 2$ (Valence: positive vs. negative) withinparticipants ANOVA. This analysis yielded a significant interaction between emotion and group, $F(1$, $160)=9.63, p=.002, \eta_{\mathrm{p}}^{2}=.06$. As expected, this interaction indicated that participants attributed fewer uniquely human emotions to the outgroup $(M=3.48)$ than the ingroup $(M=4.56), F(1$, $160)=102.72, p<.001, \eta_{\mathrm{p}}^{2}=.39$. In contrast with most studies on infrahumanization (see, e.g., Leyens et al., 2001), the same pattern was also found for primary emotions, that is, participants attributed the primary emotions less to the outgroup $(M=3.50)$, than the ingroup $(M=4.28), F(1$, $160)=50.29, p<.001, \eta^{2}=.24$. Importantly, neither effect was qualified by the emotion valence, $F_{s}<1.15, n s$. These findings led us to calculate both an infrahumanization index (the composite score of secondary emotions attributed to the outgroup minus the composite score of secondary emotions attributed to the ingroup) and an index for primary emotions (the composite score of primary emotions attributed to the outgroup minus the composite score of primary emotions attributed to the ingroup).

Table 1 shows the correlations, means, and standard deviations for the index of each variable in the study. Participants reported low levels of perspective taking $(M=2.38 ; S D=1.31)$ and trust

Table 1. Correlations, Means, and Standard Deviations for Composite Variables

\begin{tabular}{|c|c|c|c|c|c|c|c|}
\hline Variables & 1 & 2 & 3 & 4 & 5 & 6 & 7 \\
\hline 1. Extended contact & - & & & & & & \\
\hline 2. "Relative" common-ingroup identification & .14 & - & & & & & \\
\hline 3. Trust & $.38 * * *$ & $.26^{* * * *}$ & - & & & & \\
\hline 4. Perspective taking & $.34 * * *$ & $.29 * * *$ & $.48 * * *$ & - & & & \\
\hline $\begin{array}{l}\text { 5. Infrahumanization (Differential attribution of } \\
\text { secondary emotions) }\end{array}$ & $-.21 * *$ & $-.24 * *$ & $-.19 *$ & -.09 & - & & \\
\hline 6. Differential attribution of primary emotions & -.07 & -.15 & -.02 & -.10 & $.60 * * *$ & - & \\
\hline 7. Competitive victimhood & $-.30 * * *$ & $-.19 *$ & $-.43 * * *$ & $-.50 * * *$ & $.24 * *$ & -.14 & - \\
\hline$M$ & 1.67 & .05 & 2.70 & 2.38 & 1.05 & .54 & 4.25 \\
\hline$S D$ & 1.54 & .99 & 1.41 & 1.31 & 1.34 & 1.09 & 1.79 \\
\hline
\end{tabular}

Note: $N=151 ; * \leq .05 . * * p \leq .01 . * * * p \leq .001$. 
$(M=2.70 ; S D=1.41)$ toward the outgroup. The index of competitive victimhood was greater than zero $(t(150)=29.31, p<.001)$, suggesting that, on average, participants perceived their own group as more victimized than the outgroup.

As can be seen in Table 1 , extended contact $(r=.38, p<.001)$ and relative common ingroup identification $(r=.26, p=.001)$ were positively correlated with intergroup trust. This was, in turn, negatively correlated $(r=-.43, p<.001)$ with competitive victimhood. Furthermore, as predicted, extended contact $(r=.34, p<.001)$ and relative common ingroup identification $(r=.29, p<.001)$ were positively correlated with perspective taking, which was in turn negatively correlated $(r=-.50$, $p<.001)$ with competitive victimhood. Finally, extended contact $(r=-.21, p=.01)$ and relative common ingroup identification $(r=-.24, p=.004)$ were negatively correlated with outgroup infrahumanization, which was in turn positively correlated $(r=.24, p=.03)$ with competitive victimhood.

The index of primary emotions was unrelated to either the predictors or the criterion variable, suggesting that its role was not influential in the hypothesized relations (see also Tam et al., 2007). Thus, we did not include this index in further analyses.

\section{Path Modeling}

To test the hypothesized relationships between the constructs, a causal path analysis was applied (LISREL 8.7; Jöreskog \& Sörbom, 2004). In the proposed structural model (Figure 1), extended contact and "relative" common identification were entered as exogenous variables; perspective taking, trust, and outgroup infrahumanization served as mediators; competitive victimhood was the criterion variable.

The model's goodness of fit was assessed by considering the chi-square test, the root-mean square error of approximation (RMSEA), the standardized root-mean-square residual (SRMR), and the comparative fit index (CFI). A satisfactory fit between the data and the model is indicated by a nonsignificant chi-square test, an RMSEA value less than or equal to .06, an SRMR value less than or equal to .08 , and a CFI value greater than or equal to .95 (Hu \& Bentler, 1999). In testing the

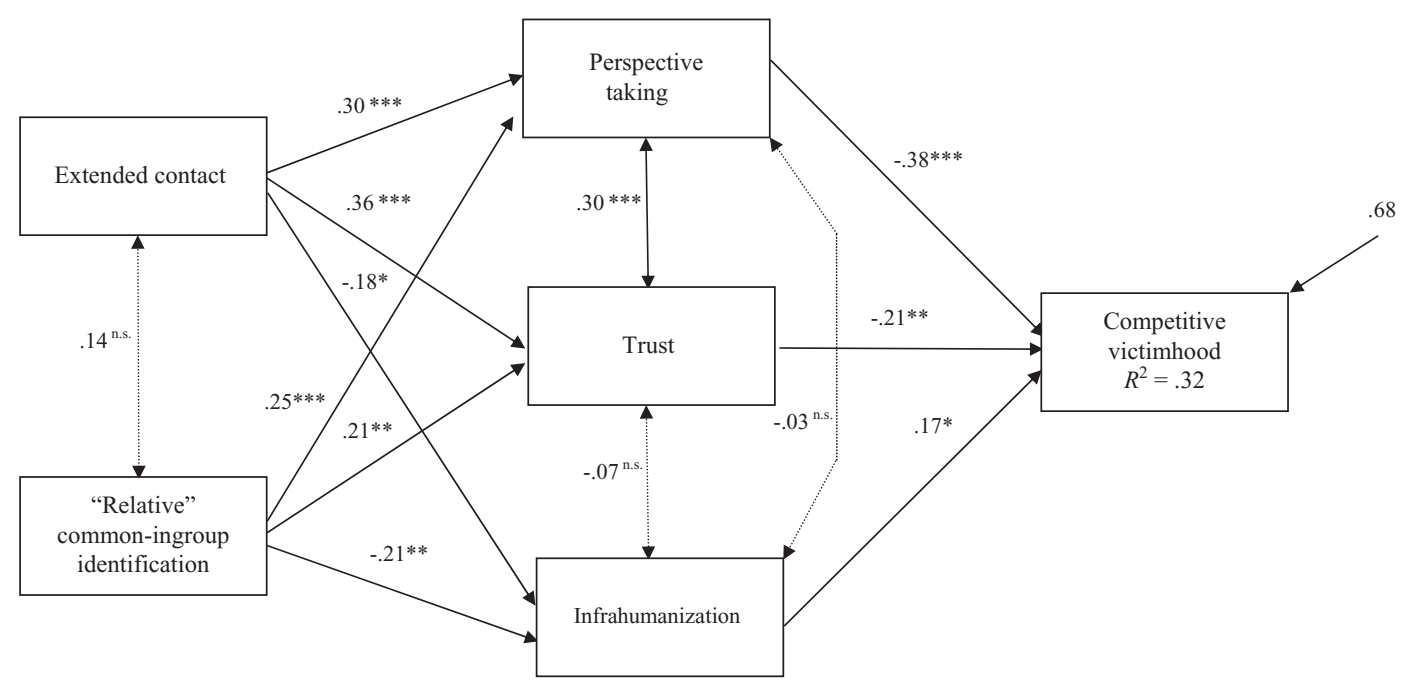

Figure 1. Structural equation model of the effects of indirect contact and "relative" common-ingroup identification on competitive victimhood, showing mediation of perspective taking, trust, and infrahumanization. Dashed lines indicate a nonsignificant path. 
model, we set free the correlations between the exogenous variables and between the mediator variables.

The tested model fit the data well: $\chi^{2}(2)=.72, p=.70 ; \mathrm{CFI}=1.00 ; \mathrm{RMSEA}=.00 ; \mathrm{SRMR}=.011$. Figure 1 shows that people with more frequent and positive extended contact with Serbians tended to empathize more with the outgroup members $(\gamma=.30, p=<.001)$, to trust them more $(\gamma=.36$, $p<.001)$, and to perceive less difference between ingroup and outgroup members' ability to experience uniquely human emotions $(\gamma=-.18, p=.03)$. Similarly, our findings indicated that the "relative" common ingroup identification affected all three mediator constructs by increasing perspective taking $(\gamma=.25, p=.001)$ and trust $(\gamma=.21, p=.006)$, and decreasing outgroup infrahumanization $(\gamma=-.21$, $p=.008)$. In turn, as expected, both perspective taking $(\beta=-.38, p<.001)$ and trust $(\beta=-.21$, $p=.007)$ were associated with decreased competitive victimhood. Inversely, infrahumanization was a positive predictor of respondents' levels of competitive victimhood $(\beta=.17, p=.02)$. Overall, the model accounted for $32 \%$ of the variance in the measure of competitive victimhood.

Furthermore, we examined the residual direct effects of extended contact and common ingroup identification on our criterion variable by performing nested models with LISREL. The two models including each direct path were compared to the baseline mediation model. Chi-square difference tests were computed to check the significance of these direct paths. Nonsignificant chi-square differences indicate full mediation. In contrast, a significant direct path indicates a partial mediation (see, e.g., Kline 1998). Findings revealed no significant residual direct effects for extended contact $\left(\gamma=-.06, n s ; \chi_{\mathrm{d}}^{2}[1]=0.70, n s\right)$ or common ingroup identification $\left(\gamma=-.01, n s ; \chi_{\mathrm{d}}^{2}[1]=0.03, n s\right)$.

To assess the overall effect exerted by each factor on the criterion variable and the strength of the mediation effects, we also carried out an effect decomposition (Loehlin, 1998). The total effect (TE) of extended contact on competitive victimhood $(\mathrm{TE}=-.22, p<.001)$ was slightly greater than the total effect of "relative" common ingroup identification $(\mathrm{TE}=-.17, p<.001)$. Notably, the indirect effect (IE) that each predictor variables exerted on the criterion variable was also significant and of the same strength of the total effect (extended contact-to-competitive victimhood, $\mathrm{IE}=-.22$, $p<.001$; "relative" common ingroup-to-competitive victimhood, $\mathrm{IE}=-.17, p<.001$ ), confirming that the effects of the predictors were totally mediated by the considered mediators, i.e., perspective taking, trust, and infrahumanization.

Additionally, we also conducted a series of Sobel tests (Baron \& Kenny, 1986) to verify whether any of the three hypothesized variables were significant mediators. The Sobel tests showed that trust was a significant mediator in the relationship between extended contact and common ingroup identification $(z=3.45 ; p<.001)$. Trust also significantly mediated the effects of the strength of common ingroup identification on competitive victimhood $(z=2.74 ; p=.006)$. Furthermore, perspective taking was found to significantly mediate both of the above-mentioned relationships $\left(z_{\text {extended contact }}=-3.52, p<.001 ; z_{\text {common ingroup identification }}=-3.20, p=.001\right)$. Outgroup infrahumanization marginally mediated the two relationships ( $z_{\text {extended }}$ contact $=-1.75, p=.081 ; z_{\text {common ingroup identification }}$ $=-1.91, p=.056)$.

\section{Alternative Models}

Although our theoretical model fit the data extremely well, we also considered three alternative models. Indeed, because our data are cross-sectional, they cannot provide inferences about the causal relationships between the variables. As suggested by a previous study on competitive victimhood (Noor et al., 2008), a higher perception that one's ingroup has been more victimized than the outgroup may also produce a decrease of trust. We therefore tested the model in which extended contact and common ingroup identification predicted competitive victimhood, and this in turn influenced trust, perspective taking and infrahumanization. This model did not provide a good fit: $\chi^{2}(6)=31.86, p<.001 ; \mathrm{CFI}=0.87$; RMSEA $=.17$; SRMR $=.010$. The two other alternative models 
were designed according to the literature on CIIM (see Gaertner, Rust, Dovidio, Bachman, \& Anastasio, 1994), which suggests that contact (in our case extended contact) strengthens the identification with the common ingroup. In the first one, extended contact was entered as a predictor of common ingroup identification which in turn predicted competitive victimhood through perspective taking, trust, and infrahumanization. The goodness-of-fit statistics for this alternative model were also unsatisfactory: $\chi^{2}(5)=27.84, p<.001$; CFI $=0.81$; RMSEA $=.12$; SRMR $=.018$. In the second model, extended contact was entered as a predictor of both common ingroup identification and competitive victimhood, which in turn predicted perspective taking, trust, and infrahumanization. Again, the fit indices were not satisfactory: $\chi^{2}(4)=21.80, p<.001 ; \mathrm{CFI}=0.91$; RMSEA $=.17$; $\mathrm{SRMR}=.083$. Thus, we can conclude that our hypothesized model provided the best model fit.

\section{Discussion}

The primary aim of this research was to identify social-psychological factors that contribute to weaken competitive victimhood, that is, one group's tendency to compete with an outgroup to obtain the highest status of victimhood. Although previous studies (Noor, Brown et al., 2008; Noor et al., 2008) have demonstrated the detrimental effects of competitive victimhood on reconciliation processes, to our knowledge, no study has yet investigated its potential inhibitors. To achieve this, we proposed a model in which positive extended contact and common ingroup identification were hypothesized as predictors of competitive victimhood. Furthermore, in our model, intergroup trust, willingness to understand outgroup perspectives (i.e., perspective taking), and outgroup infrahumanization (i.e., the greater attribution of human emotions to the ingroup than the outgroup) were expected to fully mediate these associations. Unlike many studies investigating intergroup relations, the current study was conducted in an actual postconflict setting characterized by recent intergroup violence. The suggested model fit the data extremely well. Consistent with the expectations, the findings revealed that both extended contact and common ingroup identification negatively predicted competitive victimhood, by enhancing intergroup trust and perspective taking and by reducing the tendency to infrahumanize outgroup.

Consistent with previous literature (e.g., Tam et al., 2009), our results provide further evidence of the beneficial impact of extended contact on intergroup reconciliation processes. The mere knowledge that members of one's family had frequent and good-quality contact with outgroup members decreased the participants' willingness to engage in competitive victimhood. It is worth noting that this evidence emerged in a highly segregated context, where extended contact is the primary and practically the only source of contact. Indeed, in our study, most participants reported having no direct contact with outgroup members. Additionally, the most consistent source of extended contact was relationships between participants' family members and outgroup members. This is not surprising, because older family members (parents, grandparents) may rely on positive intergroup relationships nourished before the conflict, when the level of segregation between the two communities was somewhat less embedded in society. It is also noteworthy that our measure of extended contact did not require friendship between ingroup and outgroup members, but simply positive intergroup contact. This result appears relevant especially for highly charged intergroup settings, where people may be reluctant to admit that a family member or friend has a friend who belongs to the outgroup.

In examining common ingroup identification, we assumed that in Kosovo, where significant overlap exists between the ingroup (Albanians) and the larger, more inclusive superordinate group (inhabitants of Kosovo; Čehajić et al., 2008; see also Noor et al., 2008), a more reliable predictor of intergroup reconciliation would be a relative common ingroup identification, broken up from the effects of ingroup identification. Our results supported this rationale. Although common ingroup identification per se was not related with competitive victimhood or any mediator variable, the strength of the "relative" common ingroup identification significantly predicted a decrease in 
competitive victimhood. This finding meaningfully contributes to the existing research on common ingroup identity (Gaertner \& Dovidio, 2000), by showing the positive effects on intergroup attitudes among natural groups that have experienced high degrees of intergroup violence.

In our investigation, intergroup trust was a key factor in explaining the effects of extended contact and common ingroup identification on competitive victimhood. If positive extended contact and common ingroup identification promote trust, as suggested elsewhere (Dovidio et al., 1997; Tam et al., 2009), this in its turn weakens the tendency toward competitive victimhood. Here, we hypothesized and found a reversed path between trust and competitive victimhood compared to the reconciliation orientation model (ROM) proposed by Noor et al. (2008). However, as suggested by the same authors, it is possible to imagine a recursive relationship between these two constructs. Indeed, prior levels of competitive victimhood may influence the levels of intergroup trust, which in turn may affect subsequent levels of competitive victimhood. In any case, it is important to note that our data did not support the causal relationship demonstrated in the ROM. Given the correlational nature of this study, future longitudinal studies are needed to determine the direction of this path.

Cognitive empathy (i.e., perspective taking) and outgroup infrahumanization also explained the effects of extended contact and common ingroup identification. This study is the first to provide empirical evidence that empathy and infrahumanization can mediate the relationship between extended contact and attitude toward the outgroup. However, it is important to note that we considered only the cognitive aspect of empathy. Given that extended contact is an experience predominantly cognitive rather than affective (Paolini et al., 2007; Wright et al., 1997), it is plausible that considering emotional empathy would produce different results.

The results obtained for the infrahumanization need some consideration as well. In most studies on such phenomena, primary emotions are not used to differentiate the ingroup from the outgroup, because they are not uniquely human characteristics. Instead, our findings showed that Albanian participants were more likely to attribute the experience of primary emotions to the ingroup than the outgroup. This greater attribution of primary emotions may reflect a cultural stereotype that an Albanian ingroup is seen as more emotional than a Serbian outgroup (for similar results, see Paladino, Vaes, Castano, Demoulin, \& Leyens, 2004). However, this interpretation is only speculative and is not based on empirical data. What certainly matters is that our findings revealed that only the differential attribution of uniquely human emotions is implicated in the reduction of competitive victimhood, whereas the primary emotion index is unrelated with each variable considered in the model.

Overall, our findings may have important implications for peacemakers. First, they highlight the importance of extended contact in contexts where direct-contact-based interventions are difficult to establish. In particular, one way to reduce competitive victimhood would be to encourage educational interventions in which participants learn about outgroup suffering through the narratives and stories of older family members. However, despite our focus on extended contact, we believe it is important to not forget the importance of direct contact, which is the most powerful way to reduce negative intergroup attitudes (Turner et al., 2007). Thus, planned interventions based on extended contact should run parallel to projects aimed at reducing segregation and increasing opportunities for positive intergroup contact, so that group members can gain knowledge about outgroup victimization. A good example of this intervention type is offered by "Operazione Colomba" (2008; an Italian NGO), which has organized multiethnic groups in Gorazdevac (a Serbian village in West Kosovo) that allow participants to discuss the recent conflict.

Second, these results emphasize the importance of creating a superordinate entity, a sense of "we", in which both conflicting groups can identify themselves. In Kosovo, the existence of parallel Serbian institutions in most domains of everyday life (security, health care, school) strongly hinders the development of a common ingroup entity. Dismantling these parallel institutions and creating a unified political structure may be an important step (Organization for Security and Co-operation in 
Europe, 2007) toward creating a meaningful common ingroup identity recognized by both ethnic Albanians and Serbs.

There are some limitations that should be considered in interpreting our findings and in determining the direction of future research. As already mentioned, the correlational nature of the research design makes it difficult to establish the direction of the causal relation between variables.

It is likely that the relationships between variables are bidirectional and dynamic, meaning that intergroup attitudes affect competitive victimhood, which, in turn, affects intergroup attitudes. A longitudinal study would be an important next step toward determining the definitive directions of these paths, because it would permit stronger inferences about causality.

Our model accounted for $32 \%$ of the variance in our criterion variable, competitive victimhood. Although this value is satisfactory, other variables, both sociodemographic (e.g., town of residence during the war) and psychological (e.g., collective guilt) may have an impact on competitive victimhood and are sources of unaccounted variance in our model (for an example of the mediating role of collective guilt in the interpretation of a conflict, see Mari, Andrighetto, Gabbiadini, Durante, $\&$ Volpato, 2010). Therefore, future studies must take into account potential antecedents of competitive victimhood in addition to those considered in the present model.

Moreover, future investigation is needed to determine whether the reduction of competitive victimhood can be associated with positive outcomes for postconflict intergroup relations, such as a greater inclination to forgive others. We acknowledge also a potential limitation stemming from the process of questionnaire translation. Future research should better address cross-cultural adaptation concerns by adopting a more stringent translation process, which includes a back translation technique (see, e.g, Brislin, 1980) and a pretest of the measures.

Finally, the present study considered only the Albanian community. An empirical investigation of competitive victimhood and its antecedents in a Serbian sample may be particularly relevant. Indeed, the Serbs' sense of collective victimhood for their past experiences of violence has endured through the centuries and continues to this day (Mylonas, 2003), and it has likely influenced their actions toward other ethnic groups.

\section{Conclusions}

In this article, we did not intend to devalue the experiences of victims of this intractable conflict. On the contrary, we assert that the communities entrapped in this conflict experience tremendous psychological and physical sufferings. However, it is well documented that both communities involved in the conflict tend to view themselves as the conflict's only victims (see, e.g., Bar-Tal et al., 2009), and in some circumstances even compete with the outgroup to determine which group has suffered more. The so-called competitive victimhood has detrimental effects on reconciliation processes, feeding the hatred between groups long after the conflict is formally resolved. It is therefore essential to understand the psychological processes behind this tendency. To the best of our knowledge, the present study represents the first empirical report of social psychological strategies that can decrease competitive victimhood. We hope that our work provides a foundation for planning real interventions aimed at reducing intergroup animosity in postconflict settings.

\section{ACKNOWLEDGMENTS}

We wish to thank Caritas Kosovo, Caritas Italia, and the Self-Help Center of Prishtina for their generous support during this research. We would also like to thank Dr. Valon Ismajli for translating questionnaires into Albanian, and Drs. Chiara Borgonovo, and Claudia Nicoletti for their help with data collection. Finally, a special debt of gratitude is owed to Dr. Alessandro Cadorin for his decisive influence on this study. Correspondence concerning this article should be sent to Luca Andrighetto, 
Università di Milano-Bicocca, Dipartimento di Psicologia, Piazza dell’Ateneo Nuovo 1, 20126, Milano, Italy. E-mail: luca.andrighetto@unimib.it

\section{REFERENCES}

Aberson, C. L., \& Haag, S. C. (2007). Contact, perspective taking, and anxiety as predictors of stereotype endorsement, explicit attitudes, and implicit attitudes. Group Processes and Intergroup Relations, 10, 179-201.

Ajduković, D., \& Čorkalo Biruški, D. (2004). Trust and betrayal in war. In E. Stover \& H. M. Weinstein (Eds.), My neighbor, my enemy: Justice and community in the aftermath of mass atrocity (pp. 287-302). Cambridge: Cambridge University Press.

Allport, G. W. (1954). The nature of prejudice. New York: Addison-Wesley.

Bandura, A. (1999). Moral disengagement in the perpetration of inhumanities. Personality and Social Psychology Review, 3 , 193-209.

Baron, R. M., \& Kenny, D. A. (1986).The moderator-mediator variable distinction in social psychological research: Conceptual, strategic and statistical considerations. Journal of Personality and Social Psychology, 51, 1173-1182.

Bar-Tal, D. (1989). Delegitimization: The extreme case of stereotyping and prejudice. In D. Bar-Tal, C. F. Graumann, A. W. Kruglanski, \& W. Stroebe (Eds.), Stereotyping and prejudice: Changing conceptions (pp. 169-182). New York: Springer-Verlag.

Bar-Tal, D. (2007). Living with the conflict: Socio-psychological analysis of the Israeli-Jewish society. Jerusalem: Carmel (in Hebrew).

Bar-Tal, D., Chernyak-Hai, L., Schori, N., \& Gundar, A. (2009). A sense of self-perceived victimhood in intractable conflicts. International Review of the Red Cross, 91, 229-258.

Bloom, J. D., Hoxha, I., Sambunjak, D., \& Sondorp, E. (2007). Ethnic segregation in Kosovo's post-war health care system. The European Journal of Public Health, 17, 430-436.

Brewer, M. (2000). Reducing prejudice through cross-categorization: Effects of multiple social identities. In S. Oskamp (Ed.), Reducing prejudice and discrimination (pp. 165-183). Hillsdale, NJ: Erlbaum.

Brewer, M., \& Brown, R. J. (1998). Intergroup relations. In D. T. Gilbert, S. T. Fiske, \& G. Lindzey (Eds.), Handbook of social psychology (pp. 554-594). New York: McGraw-Hill.

Brislin, R. W. (1980). Translation and content analysis of oral and written material. In H. C. Triandis \& J. W. Berry (Eds.), Handbook of cross cultural psychology (pp. 389-444). Boston: Allyn \& Bacon.

Brown, R., Condor, S., Mathews, A., Wade, G., \& Williams, J. A. (1986). Explaining intergroup differentiation in an industrial organization. Journal of Occupation Psychology, 59, 273-286.

Brown, R., Maras, P., Masser, B., Vivian, J., \& Hewstone, M. (2001). Life on the ocean wave: Testing some intergroup hypotheses in a naturalistic setting. Group Processes and Intergroup Relations, 4, 81-97.

Cairns, E., Mallet, J., Lewis, C., \& Wilson, R. (2003). Who are the victims? Self-assessed victimhood and the Northern-Irish conflict. NIO Research and Statistical Series, Report No.7. Belfast: NISRA.

Caplan, N. (1999). Victimhood and identity: Psychological obstacles to Israeli reconciliation with the Palestinians. In K. Abdel-Malek \& D. C. Jacobson (Eds.), Israeli and Palestinian identities in history and literature (pp. 63-86). New York: St Martin's Press.

Capozza, D., Boccato, G., Andrighetto, L, \& Falvo, R. (2009). Categorization of ambiguous human/ape faces: Protection of ingroup but not outgroup humanity. Group Processes and Intergroup Relations, 12, 777-786.

Capozza, D., Vezzali, L., Trifiletti, E., Falvo, R., \& Favara, I. (2010). Improving intergroup relationships within and outside the contact situation: The role of common ingroup identity and emotions of empathy and anxiety. Testing, Psychometrics, Methodology in Applied Psychology, 17, 17-36.

Castano, E., \& Giner-Sorolla, R. (2006). Not quite human: Infrahumanization in response to collective responsibility for intergroup killing. Journal of Personality and Social Psychology, 90, 804-818.

Čehajić, S., Brown, J. R., \& Castano, E. (2008). Forgive and forget? Antecedents and consequences of intergroup forgiveness in Bosnia and Herzegovina. Political Psychology, 29, 351-367.

Crisp, R. J., Stathi, S., Turner, R. N., \& Husnu, S. (2008). Imagined intergroup contact: Theory, paradigm, and practice. Social and Personality Psychology Compass, 2, 1-18.

Cuddy, A. J. C., Rock, M., \& Norton, M. I. (2007). Aid in the aftermath of Hurricane Katrina: Inferences of secondary emotions and intergroup helping. Group Processes and Intergroup Relations, 10, 107-118.

Davis, M. H. (1994). Empathy: A social psychological approach. Madison, WI: Brown and Benchmark.

Demoulin, S., Leyens, J.-Ph., Paladino, M. P., Rodriguez, R. T., Rodriguez, A. P., \& Dovidio, J. F. (2004). Dimensions of uniquely and nonuniquely human emotions. Cognition and Emotion, 18, 71-96. 
Dovidio, J. F., Gaertner, S. L., \& Saguy, T. (2009). Commonality and the complexity of "we": Social attitudes and social change. Personality and Social Psychology Review, 13, 3-20.

Dovidio, J. F., Gaertner, S. L., Validzic, A., Matoka, K., Johnson, B., \& Taylor, S. (1997). Extending the benefits of re-categorization: Evaluations, self-disclosure and helping. Journal of Experimental Social Psychology, 33, 401420.

Dovidio, J. F., ten Vergert, M., Stewart, T. L., Gaertner, S. L., Johnson, J. D., Esses, V. M., Riek, B. M., \& Pearson A. R. (2004). Perspective and prejudice: Antecedents and mediating mechanisms. Personality and Social Psychology Bulletin, $30,1537-1549$.

Gaertner, S. L., \& Dovidio, J. F. (2000). Reducing intergroup bias: The common ingroup identity model. Philadelphia: Psychology Press.

Gaertner, S. L., Rust, M. C., Dovidio, J. F., Bachman, B. A., \& Anastasio, P. A. (1994). The contact hypothesis: The role of a common ingroup identity on reducing intergroup bias. Small Group Research, 25, 224-249.

Galinsky, A. D., \& Ku, G. (2004). The effects of perspective taking on prejudice: The moderating role of self-evaluation. Personality and Social Psychology Bulletin, 30, 599-604.

Galinsky, A. D., \& Moskowitz, G. B. (2000). Perspective taking: Decreasing stereotype expression, stereotype accessibility, and ingroup favoritism. Journal of Personality and Social Psychology, 78, 708-724.

Gaunt, R. (2009). Superordinate categorization as a moderator of mutual infrahumanization. Group Processes and Intergroup Relations, 12, 731-746.

Hadjipavlou, M. (2007). The Cyprus conflict: Root causes and implications for peacebuilding. Journal of Peace Research, 44, 349-365.

Harwood, J., Hewstone, M., Paolini, S., \& Voci, A. (2005). Grandparent-grandchild contact and attitudes toward older adults: Moderator and mediator effects. Personality and Social Psychology Bulletin, 31, 393-406.

Haslam, N., Loughnan, S., Kashima, Y., \& Bain, P. (2008). Attributing and denying humanness to others. In W. Stroebe \& M. Hewstone (Eds.), European review of social psychology (Vol. 19, pp. 55-85). Hove, UK: Psychology Press.

Hewstone, M., Cairns, E., Kenworthy, J., Hughes, J., Tausch, N., Voci, A., von Hecker, U., \& Pinder, C. (2008). Stepping stones to reconciliation in Northern Ireland: Intergroup contact, forgiveness and trust. In A. Nadler, T. E. Malloy, \& J. D. Fisher (Eds.), The social psychology of intergroup reconciliation (pp. 199-226). New York: Oxford University Press.

Hewstone, M., Cairns, E., Voci, A., Hamberger, J., \& Niens, U. (2006). Intergroup contact, forgiveness, and experience of "the Troubles" in Northern Ireland. Journal of Social Issues, 62, 99-120.

Hewstone, M., Rubin, M., \& Willis, H. (2002). Intergroup bias. Annual Review of Psychology, 53, 575-604.

Hu, L., \& Bentler, P. M. (1999). Cutoff criteria for fit indexes in covariance structure analysis: Conventional criteria versus new alternatives. Structural Equation Modeling, 6, 1-55.

Internal Displacement Monitoring Center. (2009). IDPs still seeking housing solutions and documentation to access their rights. Retrieved 10 May 2010 from http://www.internal-displacement.org

Jöreskog, K. G., \& Sörbom, D. (2004). LISREL 8.7 for Windows [Computer Software]. Lincolnwood, IL: Scientific Software International, Inc.

Kelmendi, M., \& Desku, A. (Eds.). (2005). Who is Kosovar? Kosovar identity [a debate]. Prishtina, Kosovo: Java Multimedia.

Kline, R. B. (1998). Principles and practice of structural equation modeling. New York: Guilford Press.

Kosic, A., \& Tauber, C. D. (2010). Promoting reconciliation through youth: Cross-community initiatives in Vukovar (Croatia). Peace and Conflict: Journal of Peace Psychology, 16, 81-95.

Kostovicova, D. (2005). Kosovo: The politics of identity and space. New York: Routledge.

Kostovicova, D. (2009). Albanian parallel education system and its aftermath: Segregation, identity and governance. In Dimou, A. (Ed.), 'Transition' and the politics of history education in Southeast Europe (pp. 201-215). Goettingen, Germany: Vanderhoeck und Ruprecht.

Kramer, R. M., \& Carnevale, P. J. (2001). Trust and intergroup negotiation. In R. J. Brown \& S. L. Gaertner (Eds.), Blackwell handbook of social psychology, vol 4: Intergroup relations (pp. 431-450). Oxford: Blackwell.

Leyens, J.-Ph., Cortes, B. P., Demoulin, S., Dovidio, J. F., Fiske, S. T., Gaunt, R., . . Vaes, J. (2003). Emotional prejudice, essentialism, and nationalism. European Journal of Social Psychology, 33, 703-717.

Leyens, J.-Ph., Demoulin, S., Vaes, J., Gaunt, R., \& Paladino, M. P. (2007). Infrahumanization: The wall of group differences. Social Issues and Policy Review, 1, 139-172.

Leyens, J.-Ph., Rodriguez-Perez, A., Rodriguez-Torres, R., Gaunt, R., Paladino, M. P., Vaes, J., \& Demoulin, S. (2001). Psychological essentialism and the differential attribution of uniquely human emotions to ingroups and outgroups. European Journal of Social Psychology, 31, 395-411.

Loehlin, J. C. (1998). Latent variable models: An introduction to factor, path, and structural analysis (3rd ed.). Mahwah, NJ: Lawrence Erlbaum. 
Mari, S., Andrighetto, L., Gabbiadini, A., Durante, F., \& Volpato, C. (2010). The shadow of the Italian colonial experience: The impact of collective emotions on intentions to help the victims' descendants. International Journal of Conflict and Violence, 4, 58-74.

Mitchell, C. (2000). Gestures of conciliation factors contributing to successful olive branches. London: Macmillan.

Myers, E., Hewstone, M., \& Cairns, E. (2009). Impact of conflict on mental health in Northern Ireland: The mediating role of intergroup forgiveness and collective guilt. Political Psychology, 30, 269-290.

Mylonas, C. (2003). Serbian orthodox fundamentals: The quest for an eternal identity. Budapest: Central European University Press.

Nadler, A., Malloy, T. E., \& Fisher, J. D. (Eds.). (2008). Social psychology of intergroup reconciliation. New York: Oxford University Press.

Nadler, A., \& Saguy, T. (2003). Reconciliation between nations: Overcoming emotional deterrents to ending conflicts between groups. In H. Langholtz \& C. E. Stout (Eds.), The psychology of diplomacy (pp. 29-46). Westport, CT: Praeger.

Noor, M., Brown, J. R., Gonzalez, R., Manzi, J., \& Lewis, C. A. (2008). On positive psychological outcomes: What helps groups with a history of conflict to forgive and reconcile with each other? Personality and Social Psychology Bulletin, 34, 819-832.

Noor, M., Brown, J. R., \& Prentice, G. (2008). Precursors and mediators of intergroup reconciliation in Northern Ireland: A new model. Journal of British Social Psychology, 47, 481-495.

Operazione Colomba. (2008). http://www.operazionecolomba.com/

Organization for Security and Co-operation in Europe. (2007). Parallel Structures in Kosovo. Retrieved 15 June 2010 from http://www.osce.org.

Paladino, M. P., Vaes, J., Castano, E., Demoulin, S., \& Leyens, J.-Ph. (2004). Emotional infra-humanization in intergroup relations: The role of national identification in the attribution of primary and secondary emotions to Italians and Germans. Cahiers de Psychologie Cognitive/Current Psychology of Cognition, 22, 519-536.

Paolini, S., Hewstone, M., \& Cairns, E. (2007). Direct and indirect friendship effects: Testing the moderating role of the affective-cognitive bases of prejudice. Personality and Social Psychology Bulletin, 33, 1406-1420.

Paolini, S., Hewstone, M., Cairns, E., \& Voci, A. (2004). Effects of direct and indirect cross-group friendships on judgments of Catholics and Protestants in Northern Ireland: The mediating role of an anxiety-reduction mechanism. Personality and Social Psychology Bulletin, 30, 770-786.

Pettigrew, T. F., \& Tropp, L. R. (2006). A meta-analytic test of intergroup contact theory. Journal of Personality and Social Psychology, 90, 751-783.

Phinney, J. S., Ferguson, D. L., \& Tate, J. D. (1997). Intergroup attitudes among ethnic minority adolescents. Journal of Early Adolescence, 9, 34-49.

Reynolds, K. J., \& Turner. J. C. (2001). Prejudice as a group process: The role of social identity. In M. Augoustinos \& K. J. Reynolds (Eds.), Understanding prejudice, racism, and social conflict (pp. 59-79). London: Sage.

Riek, B. M., Mania, E. W., Gaertner, S. L., McDonald, S. A., \& Lamoreaux, J. M. (2010). Does a common ingroup identity reduce intergroup threat? Group Processes and Intergroup Relations, 12, 731-746.

Robben, A., \& Suarez-Orozco, R. (2000). Cultures under siege: Collective violence and trauma. Cambridge: Cambridge University Press.

Rouhana, N., \& Bar-Tal, D. (1998). Psychological dynamics of intractable ethno-national conflicts: The Israeli-Palestinian case. American Psychologist, 53, 761-770.

Rosenberg, M. (1957). Occupations and values. Glencoe, IL: Free Press.

Shnabel, N., \& Nadler, A. (2008). A needs-based model of reconciliation: Satisfying the differential emotional needs of victim and perpetrator as a key to promoting reconciliation. Journal of Personality and Social Psychology, 94, 116132

Smyth, M. (2001). Putting the past in its place: Issues of victimhood and reconciliation in Northern Ireland's peace process. In N. Biggar (Ed.), Burying the past: Making peace and doing justice after civil conflict (pp. 125-155). Washington, DC: Georgetown University Press.

Spiegel, P. B., \& Salama, P. (2000). War and mortality in Kosovo, 1998-1999: An epidemiological testimony. The Lancet, 355, 2204-2209.

Tajfel, H., \& Turner, J. C. (1986). The social identity theory of inter-group behavior. In S. Worchel \& L. W. Austin (Eds.), Psychology of intergroup relations (pp. 7-24). Chicago: Nelson-Hall.

Tam, T., Hewstone, M., Cairns, E., Tausch, N., Maio, G., \& Kenworthy, J. (2007). The impact of intergroup emotions on forgiveness in Northern Ireland. Group Processes and Intergroup Relations, 10, 119-136.

Tam, T., Hewstone, M., Kenworthy, J., \& Cairns, E. (2009). Intergroup trust in Northern Ireland. Group Processes and Intergroup Relations, 35, 45-59. 
Turner, R. N., Hewstone, M., \& Voci, A. (2007). Reducing explicit and implicit outgroup prejudice via direct and extended contact: The mediating role of self-disclosure and intergroup anxiety. Journal of Personality and Social Psychology, 93, 369-388.

Turner, R. N., Hewstone, M., Voci, A., Paolini, S., \& Christ, O. (2007). Reducing prejudice via direct and extended cross-group friendship. European Review of Social Psychology, 18, 212-255.

Turner, R. N., Hewstone, M., Voci, A., \& Vonofakou, C. (2008). A test of the extended contact hypothesis: The mediating role of intergroup anxiety, perceived ingroup and outgroup norms, and inclusion of the outgroup in the self. Journal of Personality and Social Psychology, 95, 843-860.

United Nations High Commissioners for Refugees. (1999). Kosovo crisis update. Retrieved 8 April 2010 from http:// www.unhcr.org/

Vescio, T. K., Sechrist, G. B., \& Paolucci, M. P. (2003). Perspective taking and prejudice reduction: The mediational role of empathy arousal and situational attributions. European Journal of Social Psychology, 33, 455-472.

Vezzali, L., Stathi, S., \& Giovannini, D. (2012). Indirect contact through book reading: Improving adolescents' attitudes and behavioral intentions toward immigrants. Psychology in the Schools, 49, 148-162.

Voci, A., \& Hewstone, M. (2003). Intergroup contact and prejudice towards immigrants in Italy: The mediational role of anxiety and the moderational role of group salience. Group Processes and Intergroup Relations, 6, 37-54.

Volkan, V. (1997). Blood lines: From ethnic pride to ethnic terrorism. Boulder, CO: Westview Press.

Wagner, U., van Dick, R., Pettigrew, T. F., \& Christ, O. (2003). Ethnic prejudice in East and West Germany: The explanatory power of intergroup contact. Group Processes \& Intergroup Relations, 6, 22-36.

Winther, M. (2007). Kosovo: A Gordian knot. Baltic Security \& Defence Review, 9, 79-108.

Wohl, M. J. A., \& Branscombe, N. R. (2005). Forgiveness and collective guilt assignment to historical perpetrator groups depends on level of social category inclusiveness. Journal of Personality and Social Psychology, 88, 288-303.

Wright, S. C., Aron, A., McLaughlin-Volpe, T., \& Ropp, S. A. (1997). The extended contact effect: Knowledge of cross-group friendships and prejudice. Journal of Personality and Social Psychology, 73, 73-90. 